\title{
HOW WAS SULTAN ALP ARSLAN KILLED?
}

\section{Muharrem KESIK ${ }^{*}$}

\begin{abstract}
This study addresses events that occurred during the last military expedition of Sultan Alp Arslan, one of the greatest rulers in Seljuq and Turkish history. Related subects include how the Sultan was killed, his will, the date of his death, where he was buried and the site of his grave. The most important sources of the period of Sultan Alp Arslan were used for this research. The results show that Sultan Alp Arslan died on 24 November 1072 as the consequence of a stab wound from the dagger of Yousef al-Khwarezmi, the commander of Berzem fortress. Sultan Alp Arslan was killed after crossing the Amudarya River during a military expedition he organized against the Western Karakhanid. Before he passed away, Sultan Alp Arslan made a dying wish that his son and heir apparent Malik-Shah I succeed him. Sultan Alp Arslan was buried in the city of Marv by his son MalikShah I.
\end{abstract}

Key Words: Sultan Alp Arslan, Marv, Yousef al-Kharezmi, Seljuqs, death.

* Associate Professor, Istanbul University Faculty of Letters, History Department Academician, muharremkesik@gmail.com 


\title{
SULTAN ALP ARSLAN NASIL ÖLDÜRÜLDÜ?
}

\begin{abstract}
ÖZ
Bu çalışma ile Selçuklu ve Türk Tarihi'nin en büyük hükümdarlarından biri olan Sultan Alp Arslan'ın son askerî seferinde yaşanan olaylar, sultanın nasıl öldürüldüğü, vasiyeti, ölüm tarihi, nerede defnedildiği ve mezar yerinin nerede bulunduğu gibi konu başlıkları ele alınmıştır. Araştırma sırasında Sultan Alp Arslan Devri'nin en önemli kaynaklarından yararlanılmıştır. Sonuç olarak Sultan Alp Arslan, Batı Karahanlılar üzerine düzenlediği askerî sefer sırasında Ceyhun Nehri'ni geçtikten sonra Berzem adlı bir kale komutanı Yusuf el-Hârezmî tarafından hançerlenmiş aldığı yaranın tesiriyle 24 Kasım 1072 günü ölmüş, ölmeden önce veliahtı ve oğlu Melikşah'ın yerine geçmesini vasiyet etmiş, oğlu tarafından Merv şehrinde defnedilmiştir.
\end{abstract}

Anahtar Kelimeler: Sultan Alp Arslan, Merv, Yusuf el-Hârezmî, Selçuklular, ölüm. 
Sultan Alp Arslan, who ruled the Great Seljuks State from 1063 to 1072, was one of the most important rulers in Turkish history. ${ }^{1}$ Alp Arslan was the son of Chagri Beg, a grandson of the father of the Seljuqs, Seljuq Bey, and he won the battle to rule following the death of Sultan ToghrulBeg, thereafter sitting on the throne at the capital Rayy. Alp Arslan made important contributions to the expansion of the borders of the Great Seljuq State and to the spread of the fame of the state throughout the world. Following his famous victory against Byzantine Emperor Romanos Diogenes at Manzikert ${ }^{2}$ on 26 August 1071, Alp Arslan eliminated the obstacles to the conquest of Anatolia and played a major role in making this territory a homeland for the Seljuqs. By taking the Emperor captive, Alp Arslan gained great fame but in 1072, on an expedition to Western Turkestan, he met with death in an unexpected way and at a relatively early age. In our investigation, we will try to bring clarity to the story of the death of this great Turkish sultan that has been the subject of differing accounts in certain sources and by some researchers. We will also try to identify his missing resting place.

\section{SULTAN ALP ARSLAN'S LAST EXPEDITION: WESTERN TURKESTAN}

Sultan Alp Arslan's decisive victory over the powerful Byzantine army at Manzikert meant that there was no longer any military force that could challenge the Seljuqs in Anatolia. So why did Sultan Alp Arslan make an agreement with Emperor Romanos and set him free, rather than occupying Anatolia, seizing Istanbul and putting an end to the Byzantine Empire, which had no way left to stop the Seljuqs? The reason was that at the time Alp Arslan had more important matters on his mind, namely ensuring that the Seljuq State control the Islamic world. This goal eclipsed the need to establish sovereignty over Christian Anatolia. The Sultan could not ignore the Shiites threat in Egypt and set out on a major military expedition. Additionally, a full-scale Seljuq attack on Byzantium would rally the rest of the Christian world to aid the Byzantines. So the factors facing Alp Arslan were the Christians in front of him, the Shii to his rear and the certainty that the Karakhanid's and Ghaznavid's, both of which accepted

${ }^{1}$ For information on Sultan Alp Arslan see M. Altay Köymen, Büyük Selçuklu Imparatorluğu Tarihi Sultan Alp Arslan ve Zamanı, Ankara 1992; Osman Turan, Selçuklular Tarihi ve Türk İslâm Medeniyeti, Istanbul 1993, pp. 147-195; Ibrahim Kafesoğlu, “Alparslan”, DİA, II, 526530.

${ }^{2}$ For detailed information about the Battle of Manzikert see Muharrem Kesik, 1071 Malazgirt Zafere Giden Yol, Istanbul 2013. 
Seljuq sovereignty grudgingly, would enter into the fray. As soon as he made the agreement with Romanos, Alp Arslan departed Anatolia because very troubling news was coming from the territory of the Western Karakhanid's. The on going wars between Sultan Alp Arslan's sons Ilyas Malik of Khwarezm and Ayaz Malik of Tokharistan, who administered the region, and the Western Karakhanid's leader Shams al-Mulk Nasr, showed no sign of stopping. While the Karakhanids ruler was in Turkestan, Malik Ayaz had organized raids on Bukhara and Samarkand. When Nasr Han got word of these Seljuq raids he returned to rout Ayaz's soldiers, killing some and taking others prisoner. ${ }^{3}$ Nasr Han also beat to death Seljuq's Khatun, his wife and Alp Arslan's daughter, whom he accused of spying for her brother Ayaz and against himself. ${ }^{4}$ These events enraged Sultan Alp Arslan who was forced to set out on an expedition to Western Turkestan. ${ }^{5}$ At the end of September 1072 (Muharram 465), the Sultan marched with an army of about $200,000^{6}$ against his son-in-law Nasr Han, the ruler of the Western Karakhanid.

This event is somewhat differently related by Sibt Ibn al-Jawzi (pp 2849)7: "Shams al-Mulk Tegin bin Tamghach, the ruler of Samarkand, Buhara and Mawarannahr (Transoxiana) married with Alp Arslan's sister. Allegedly, Shams al-Mulk Tegin killed his wife because she was inciting her brother to take over the country. Later on, Alp Arslan married Shams alMulk's sister. At this time, Malik Ayaz and Malik-Shah I (the Sultan's sons) crossed the Amuderya (Ceyhun) to fight with Shams al-Mulk who defeated the two sons and looted their goods, among which was a gold-engraved basin. When Ayaz and Malik-Shah I crossed back over the Amudarya and returned to Khorasan, Shams al-Mulk said to his wife, the sultan's sister, "you incited them to cross the Amudarya." Allegedly, he then kicked his wife and caused her death. When Sultan Alp Arslan heard of this he set out

\footnotetext{
${ }^{3}$ According to an alternative source, this sovereign was not Ayaz but rather Malik-Shah I, who would later become sultan. See Hunkan, Türk Hakanlığ Karahanlılar, p. 341.

4 Abu'l-Farac (Bar Hebraeus), Chronicon, Turkish translation by Ömer Riza Doğrul as, Abû'l-Farac Tarihi,Ankara 1987, I, 325. According to Sibt Ibn al-Jawzi, (Mir'ât al-zamân fi't tarih al-a'yan, translation Ali Sevim, "Sibt İbnü'l-Cevzî'nin Mir'âtü'z-Zaman Fî Tarihi'lÂyan Adlı Eserindeki Selçuklularla İlgili Bilgiler II. Sultan Alp Arslan Dönemi”, Belgeler, XIX/23, Ankara 1999, p.49), this was Sultan Alp Arslan's sister. See. Ö.S. Hunkan, Türk Hakanlığ Karahanlılar, Istanbul 2007, p. 341.

5 Sibt Ibn al-Jawzi, p. 48-49. Krş Turan, Selçuklular Tarihi, p. 189.

${ }^{6}$ Ibn al-Athir al-Kâmil fi'l-târikh, Turkish translation as el-Kâmil fi't-târih by Abdülkerim Özaydın, İslâm Tarihi, Istanbul 1987, X, 78, registered that Sultan Alp Arslan's force was in excess of 200,000 cavalrymen.

7 See same place.
} 
against Shams al-Mulk, who quickly sent word to the Sultan, swearing that he had not "killed the sister" and sending his own sister to Alp Arslan for marriage. After defeating the Byzantine Emperor, the Sultan entered the nuptial chamber with Shams al-Mulk's sister and loved her very much. However, Alp Arslan noticed among his bride's trousseau the gold-engraved basin that had been looted from Malik-Shah I and he said to himself Shams al-Mulk sent this basin to me to scare me and to remind me of my son's defeat.' Alp Arslan then raised a great army with the aim of marching on Shams al-Mulk. The force was said to be made up of 200,000 cavalry and foot soldiers, with which the Sultan embarked. ${ }^{8}$

\section{THE KILLING OF SULTAN ALP ARSLAN}

Although Sultan Alp Arslan's death is related rather differently in a number of sources, in general, most Islamic sources describe different details of the same event. In order to reach a solid conclusion from all of these sources we have to look at the information contained in these sources.

Matthew of Edessa, a well-known Armenian historian of the 11th and 12th centuries ${ }^{9}$, described the killing of Sultan Alp Arslan in this way: "Sultan Alp Arslan gathered up all the Iranian soldiers and crossed the Great Oxus (Amudarya/Ceyhun River), known by the name Gehon. He went there in order to seize the country of Samarkand. Riding at the head of a great army, Alp Arslan marched on the fortified and famous fortress at Hana (Berzem) and surrounded it. The owner of this fortress was a brave but wild and merciless man. For days the Sultan besieged the fortress and pressed it hard. At the same time, he invited the fortress owner to pay obeisance to himself, allowing that the owner would always be the owner of the land of his forefathers. After bearing terrible difficulties, the fortress owner decided to make a offer of supplication to the Sultan. He thought up a frightful plan. That day he had a great festival and dinner with his wife and children. With drums beating and songs being sung he had a joyful time eating and drinking with them. But at night, fearing that his wife and three sons would be taken and enslaved by the Sultan, he visciously killed them all with his own hand. The next morning he arose early and left the fortress to meet with the Sultan,

${ }^{8}$ Krş. Hunkan, age., pp. 340-342.

${ }^{9}$ The Chronicle of Matthew of Edessa, Patmut'iwn, Turkish translation by Hrant D. Andreasyan as (Urfalı Mateos Vekayi-Nâmesi (952-1136) ve Papaz Grigor'un Zeyli (11361162), Ankara 1987, p. 144-146. Osman Turan (Selçuklular Tarihi ve Türk İslâm Medeniyeti, Istanbul 1993, p. 190) used Matthew of Edessa's account as the basis when relalating the event of the death of Sultan Alp Arslan. 
bringing along the two sharp knives he had used to cut his sons. When the Sultan heard that he was coming he ordered that the fortress owner be brought to him. Entering the Sultan's presence, the fortress owner bent over but then suddenly leapt onto the Sultan as he approached him, drawing out the two knives he had concealed in his boots. Those who had brought him to the Sultan fled as the fortress owner set upon the Sultan like a wild animal, stabbing his body with the two knives. The Sultan's men rushed forward and killed the fortress owner where he stood. The Sultan was wounded in three places and in a very precarious situation, writhing in terrible pain. The Sultan gave the order for the army to move forward so that the country's populace would not be aware of the incident. Five days later, feeling himself in a dire situation, the Sultan summoned his commanders and Khojab (Hâce Hasan et-Tûsî/Vizier Nizam al-Mulk) to his side. The Sultan presented his son Malik-Shah I, the father of just one boy at this point, to them and said "I'm dying from the effects of my wounds. My son is your ruler and sits on my throne." After saying this the Sultan took off his ruling garments and put them on Malik-Shah I. He bowed before his son and with tears in his eyes entrusted Malik-Shah I to God and the important rulers. Sultan Alp Arslan died the same day in this manner, the victim of an unimportant man. As his father's successor, Malik-Shah I took the throne, carried his father's body back to their homeland and buried him in the tomb of his forefathers in the city of Marand. ${ }^{10}$,

13th century Syriac historian Abu'l Farac, ${ }^{11}$ however, had the following to say, probably based on information he obtained from İbn alAthir: Sultan Alp Arslan marched against Karakhanid's ruler Shams al-Mulk (bin Tamghach), who was also his son-in-law, and after crossing the Amudarya river ${ }^{12}$ he pitched his tents in front of a fortress, surrounding it. The ruler of the local Khwarezm populace opposed the Seljuqs but the Sultan, by duping the populace with some promises won them over and seized the fortress ruler. The Sultan then ordered that the ruler's hands and feet be tied to four sticks upon which he would be killed by a volley of arrows. Again, according to the Syriac historian, when this man was brought before the Sultan he cursed and insulted him, saying "should a man like me be killed in such a way?" This angered the Sultan and as a result he ordered that the fortress ruler's "hands and feet be untied!" The man was freed and

\footnotetext{
${ }^{10}$ A city located in Azerbaijan, 50 miles north of Tabriz (M. Halil Yinanç, Urfalı Mateos Vekayi-Nâmesi, p. 146 n. 86.

${ }^{11}$ Abû'l-Farac Tarihi, I, 325

12 The name of the river is not given in the source.
} 
the Sultan fired an arrow but missed. Seeing an opportunity, the man leapt on the Sultan, grabbed a knife and stuck it into the Sultan's back. One of the Sultan's eunuchs threw himself on the Sultan, prompting the Khwarezm (Hârezm) man to begin stabbing the eunuch. At this point, one of the Armenians setting up the tents came and killed the Khwarezm man with a blow to the head. A few days after this incident the Sultan died from his wounds and was taken to Marv and buried next to his father Chaghri Beg. According to the Sultan's will, his son Malik-Shah I took his place and his brother Qawurd Beg ${ }^{13}$ married the Sultan's wife.

Azimi, one of the historians from the Syria region of the 12th century ${ }^{14}$, does not give much information about this event, simply offering the following: "Âdil Sultan (Alp Arslan) was killed in the vicinity of the Amuderya (Ceyhun River) and his son Abu'l-Fath Malik-Shah I became sultan."

Another historian from the 12th century Syria region, Ibn alQalanisi ${ }_{1}^{15}$ presents a far different account for us. According to him, "In this year (465-1072/1073) news came that the Sultan was martyred as the result of an assassination by a mystic wearing the clothes of a Sufi ascetic." This account gives the incident an entireley different dimension. Based on what is understood from Osman Turan, ${ }^{16}$ this claim was made in the work İskenderiye Patrikleri Tarihi, which concerns Youssef of Dailami and his brother Malik Qawurd, ruler of Kerman, who had his eye on the Seljuq throne.

However, after this record appeared in the work, Sibt Ibn al-Jawzi stressed that this was not true and he asserted in no uncertain terms that the famous incident occurred as he had described.

According to İbn al-Jawzi, one of the important historians of the 12th century, ${ }^{17}$ at the beginning of the year 465 (1072-1073) Sultan Alp Arslan

\footnotetext{
${ }^{13}$ Written as "Kaurath" (Karut) in the source (Abû'l-Farac Tarihi, I, 325-326).

${ }^{14}$ Azimi, Tarikh Halab, Turkish translation Ali Sevim as Azimî Tarihi, Selçuklularla İlgili Bölümler, Ankara 1988, p. 20.

${ }^{15}$ Dhayl Tarikh Dimashq (ed. H.P. Amedroz), Leiden 1908, p. 106. In the work İskenderiye Patrikleri Tarihi (pp. 168-169), the record of Yousseff being from Dailami and having a relationship with Malik Kara Arslan Qawurd Beg ruler of Kerman, who had his eye on the Sultan's throne, is consistent with the explanations given here. (see Turan, Selçuklular Tarihi, p. 190, n. 165).

${ }^{16}$ Selçuklular Tarihi ve Türk İslâm Medeniyeti, p. 190.

${ }^{17}$ Al-Muntazam, translation Ali Sevim, in the work “İbnü'l-Cevzî'nin El-Muntazam Adlı Eserindeki Selçuklularla ilgili Bilgiler (h. 430-485=1038-1092)”, TTK Belgeler, Ankara 2005,
} 
crossed the Amudarya via a bridge that he had had built. At his side was a force of more than 200,000 cavalrymen. After this army crossed the Amudarya in the month of Safar (October/November), the Sultan's soldiers brought the fortress commander, named Yousef al-Khwarezmi, on 6 Rabi I (20 November 1072) and there were two soldiers alongside this man to keep him under control. When the Sultan learned that Youssef, whom he had brought to him, had done some bad things he scolded him and ordered that four stakes be driven so that Yousef could be tied to them. Hearing the order, Yousef said to the Sultan "hey you bad man, should a man like me be killed in this way?" This enraged the Sultan who took up his bow and arrow and order the two soldiers holding Yousef to untie his binds. The Sultan took aim at the free-standing Yousef and shot an arrow but it missed. Yousef took the opportunity to rush the Sultan who rose from his couch but stumbled and fell to the ground on his face. Right then Yousef pounced on the Sultan and stabbed him with a knife that he kept in his trousers. The soldiers immediately killed Yousef. The Sultan's wound was bandaged and he crossed back over the Amudarya. But the Sultan died here.

13th century historian Sibt Ibn al-Jawzi ${ }^{18}$, the grandson of Ibn alJawzi, related the event of the Sultan's murder as follows: "The Sultan crossed the Amudarya by means of a large bridge made up of rowboats in 24 days (Safer 465/October-November 1072). First, his forces sacked the Buhara region. Next, the Sultan's forward units surrounded a fortress named Bîrun where Yousef, a Khwarezm native, was located. After a while, the soldiers took Yousef from the fortress and brought him to the Sultan, held tightly by two Turkish soldiers (male slaves). When the Sultan saw Yousef he cursed him for all his bad deeds and insulted him. Then the Sultan had four stakes planted at the tent gate and gave the order for Yousef to be bound to them. Feeling that his minutes were numbered, Yousef said to the Sultan "Hey, bad man! Should such a man like me be killed in this way?" This enraged the Sultan who grabbed his bow and arrow, told the soldiers holding Yousef to "unbind him" and shot an arrow at him. However, the arrow missed Yousef - the first time the Sultan's arrow had not hit its mark. Yousef quickly sprang on the Sultan and stabbed him with a knife he had secreted in his trousers. Although Sa'd al-Dawla Gawhare'in tried to prevent the attack, Yousef was able to attack the Sultan with determination, stabbing him a few times and seriously wounding him. The Sultan was then taken to another tent while an Armenian sweeper (cleaner or upholsterer) split

XXVI/30, p. 52.

${ }^{18}$ Mi'rat al-zaman, p. 49. 
Yousef's head with a large axe, killing him. The Sultan ordered that Yousef's heart and guts be removed and brought to him, which they were. Both organs were quite large. Subsequently, the Sultan wounds were treated and he was brought back across the Amudarya, but he died there on Saturday, 10 Rabi'I 465 (24 November 1072).

In his work ${ }^{19}$ Ibn al-Athir (died 1233), one of the most reliable historians of the Middle Ages, explains that Sultan Alp Arslan set out on an expedition with 200,000 cavalrymen against Shams al-Mulk, the ruler of Mawarannahr, and crossed over the Amudarya River by having a bridge made in 20 days or so. ${ }^{20}$ The Sultan had two eunuchs bring Yousef alKhwarezmi, the commander of a fortress, to him on 6 Rabi'I 465 (20 November 1072) and gave the order for Yousef's arms and legs to be bound to four stakes, upon which Yousef insulted the Sultan. Yousef said to the Sultan "should such a man as me be killed in such a way?" Taking umbrage at this remark, the Sultan ordered his men to unbind Yousef and he shot an arrow at Yousef but missed - the first time up to that day that the Sultan's arrow had not hit its mark. Yousef took the opportunity to attack the Sultan who rose from his throne but stumbled and fell on his chest. Further exploiting the situation, Yousef stabbed the Sultan in the side with a knife, wounding the Sa'd al-Dawla in a number of places. The Sultan was able to get up and go to another tent while one of the servants hit Yousef in the head with a mace, killing him. The Turks then dismembered Yousef.

Information in the Anonym Saljuq-nama of the 14th century ${ }^{21}$ coincides for the most part with Ibn al-Athir's account but there are some differences, as well: "The Sultan set out for Mawarannahr (Transoxiana) in the year 464 (1071/1072) and crossed the Amudarya River, remaining there. Right away he had Yousef al-Khwarezmi Kutval of the Tirmiz Fortress, brought to him. The Sultan shot an arrow at Yousef but it missed. Sultan Alp Arslan had never missed an arrow shot before. Yousef acted before the Sultan had a chance to fire a second arrow and hit the Sultan with his own arrow. The Sultan died from his wounds on 30 Rabi'I 465 (14 December 1072). The throne passed to his son Malik-Shah I."

According to the 13th century Armenian historian Vardan Vardabet (Vardan Patmich or Vardan the Historian) ${ }^{22}$, Alp Arslan encircled a very

${ }^{19}$ Al-Kâmil fi't-tarikh, X, 78.

${ }^{20}$ Osman Turan (Selçuklular Tarihi, p. 190) records that the crossing took 24 days.

${ }^{21}$ Anonim Selçuknâme, (ed. and translator Feridun Nâfiz Uzluk), Ankara 1952, p. 13, trc. p. 8.

22 Vardan Vardabet, Universal History, Turkish translation Hrant D. Andreasyan, Türk 
well-fortified fortress on his way to Alamud. The fortress ruler gave a big feast in his house but then became very sorrowful. Then, acting as if he would be obedient to the Sultan, the fortress ruler murdered the Sultan while kissing his feet.

With regard to this subject, 13th century historian al-Bundari ${ }^{23}$ related the following: Sultan Alp Arslan crossed the Amudarya with more than 200,000 soldiers over a bridge he built over the course of a month and marched on the Karakhanid's ruler Shams al-Mulk Tegin bin Tamghach. On 6 Rabi I the Sultan's soldiers brought a fortress commander named Yousef al-Khwarezmi, along with a host of other noteables, to him. This man Yousef walked with a limp and two slaves held him tightly. Alp Arslan ordered that four stakes be driven and this man's arms and legs tied to them so he could be put to death quickly. Hearing this, Yousef shouted out "should such a man as me be killed in such a way? Shall I be treated in this manner?" The Sultan was enraged by these remarks, grabbed his bow and arrow and, giving no thought to the consequences, had the two slaves (eunuchs) holding Yousef untie his binds, freeing him. The Sultan, sitting on his throne, shot an arrow at Yousef but missed. He then got up but fell flat on his face. Seizing the opportunity, Yousef sprang on the Sultan and stabbed a knife into his side. When Yousef was brought to the Sultan, Sa'd al-Dawla Gawhare'in was standing there and Yousef wounded him in a few places, as well. The injured Sultan was brought to another tent and an Armenian sweeper hit Yousef over the head with an iron truncheon, killing him. After the Sultan related his will to Nizam al-Mulk he died.

Ibn al-Adim, ${ }^{24}$ a 13th century historian from the Syria region, recorded the Sultan's final expedition and death in the following manner: "Sultan Alp Arslan marched to the Amudarya with an army of more than 100,000 cavalrymen in the year 465 . During 20 days of the month of Safer he crossed the Amudarya and headed towards Shams al-Mulk Tegin bin Tamghach. His men brought a fortress commander named Yousef alKhwarezmi to the Sultan. There were two eunuchs by Yousef's side. The Sultan ordered that four stakes be driven and Yousef bound to them. When he realized he was about to be killed, Yousef said "hey you bastard! Should someone like me be killed in this way?" The Sultan was angered by this and

Fütuhatı Tarihi, 889-1269, Tarih Semineri Dergisi, Istanbul 1937,I/2, p. 180.

${ }^{23}$ Zubdat al-nusra wa-nukhbat al-usra, (Turkish translation by Kivameddin Burslan as, Irak ve Horasan Selçukluları Tarihi, Ankara 1943, pp. 45-47.

${ }^{24}$ Kamâl al-din Ibn al-Adim, Bughyat al-talab fi tarikh Halab, (ed. Ali Sevim as, Buğyat atTalab Fî Târîh Halap, Selçuklularla İlgili Haltercümeleri), Ankara 1976, pp. 36-37. 
grabbed his bow and arrow, ordering the two eunuchs (who were holding Yousef) to free him. The Sultan shot to kill Yousef but missed. Yousef then rushed the Sultan who rose from his throne but fell on his face, whereupon Yousef stabbed him. The Sultan entered another tent while one of the sweepers killed Yousef. Sultan Alp Arslan died, having lived for 40 years and two months after having been born in the year 424. He was buried next to his father in Marv."

Ibn al-Adim also related a tale that Sultan Alp Arslan was killed at a fortress named Berzem near the Amudarya in the year 465, on the last day of the month (14 November 1072) or the first day of the month of Rabi I (15 November 1072) and that he was buried next to his father at Marv. ${ }^{25}$

The same event was recorded by Husayni (died sometime after $1225)^{26}$ as follows: "At the beginning of the year 465 the Sultan set out on a march and passed over the Amudarya River on a bridge. There were 100,000 warrior cavalrymen with him, along with servants and eunuchs. His goal was to march on Shams al-Mulk Tamghach. The Sultan's men brought a man named Yousef al-Khwarezmi, a fortress commander, to him to be put to death for crimes he had committed. The Sultan ordered that four stakes be driven and Yousef's hands and feet bound to them. Hearing this Yousef screamed at the Sultan "Hey, fellow! Should a man be killed this way?" The Sultan became angry, grabbed his bow and arrow and ordered the guards next to Yousef to free him, which they did. The Sultan fired an arrow at Yousef but it missed. Up to that time the Sultan's arrow had never missed its mark. As the arrow missed him, Yousef rushed the Sultan who was sitting on a couch (throne). The Sultan slipped, however, as he rose up and fell on his face, giving Yousef the chance to reach him and run him through with a sword. Sa'd al-Dawla Gawhare'in was there as well and immediately intervened, wounding Yousef who nevertheless remained undetered. An Armenian sweeper hit Yousef over the head with a piece of iron and the Turks, collecting themselves, sliced Yousef up with their swords. At this time Sultan Alp Arslan stated that "I didn't intend anything, I didn't march on an foe without asking my God for help. Yesterday I went up on a hill and the ground was shaking from the magnificence of my soldiers and I felt pride. I said to myself 'I'm the ruler of the world. No one can oppose me.' But God's fate betrayed me. I ask for God's help. I ask for God's

${ }^{25}$ Buğya, p. 37.

${ }^{26}$ Akhbar al-dawlat al-saljuqiyya, translation by N. Lugal as Ahbârü'd-Devleti's-Selçukiyye, Ankara 1999, p. 37-38). 
forgiveness for the thoughts I now remember." ${ }^{27}$ The Sultan lived for three days after this and on a Saturday at the end of Rabi'I in the year 465 he died. He had been sultan for 10 years. He had sons named Malik-Shah I, Tekish (Tökiş), Ayaz, Tutuş, Böribars (Böripars) and Arslan Argun. He bequeathed his throne to Malik-Shah I. The Sultan's life had lasted forty years and two months. He was buried in Marv next to his father and uncle. ${ }^{28}$

12th century Seljuq historian Rawandi ${ }^{29}$ explained the murder of Sultan Alp Arslan thusly: "At the end of his reign the Sultan was marching to Mawarannahr in order to wage war with Ilek Khan. His mother had be from the Ilek-Khans. In the year 465, as he passed the Amudarya there was a small fortress on the shore named Berzem ${ }^{30}$ (given as "Nerzem" in the original written text). A few slaves from the lower ranks of the army seized the fortress and brought the fortress commander, named Yousef-i Berzemî, as a prisoner to the Sultan's throne. The Sultan asked Yousef about matters but Yousef did not respond properly so the Sultan ordered that Yousef be put to death. Realizing that he had no hope of living, Yousef took a dagger from his boot and attacked the Sultan. Although the Sultan's personal slaves and soldiers wanted to hold Yousef, the Sultan bellowed, grabbed his bow and arrow, and fired at Yousef but missed. Yousef then reached the Sultan and wounded him. Baghdad police superintendant Sa'd al-Dawla Gawhare'in, was standing there with the Sultan and threw himself on the Sultan. Even though he too was wounded by Yousef he did not die. There were 2,000 slaves in rows near the Sultan but not one of them rose up and intervened. Yousef-1 Berzemî (Nerzemî in the written text) fled with his dagger in his hand but Câmi'-i Nîşâbûrî, the chief sweeper, came up behind Yousef with a hammer and smashed his head, killing him then and there."

\footnotetext{
${ }^{27}$ Similar statements are found in the records of Ibn al-Jawzi and Ibn al-Athir, indicating that Al-Husayni probably took this information from one of the works of these historians.(see Ibn al-Jawzi, al-Muntazam, p. 54; Ibn al-Athir, al-Kâmil, X, 78-79, see. Bundarî, p. 47).

${ }^{28}$ Al-Husaynî (Akhbâr, p. 16) gave the same information in the section where he related the death of Sultan Tughril Beg and he records that Sultan Tughril Beg was buried next to the tomb of his brother Chaghri Beg in Marv. However, Sultan Tughril Beg's tomb is in Rayy.

${ }^{29}$ Rahat al-sudur wa-ayat al-surur, translation by Ahmed Ateş as, Râhat-üs-sudûr ve Âyet-üssürûr, Ankara 1999, pp. 118-119.

30 İn İdrisî's work Nüzhetü'l-müştâk, it is recorded as "Bûrûzem" and the place said to be a day's distance from Gurgandj (Cürcâniye) is probably Berzem fortress (see in French. tr. II, 192, see also A. Ateş, Rawandi, I, 118).
} 
The Seljuq historian Aqsarai (death 1332-1333) ${ }^{31}$ provided the following information about Sultan Alp Arslan's last expedition and death: "Alp Arslan in the last days of his reign marched on Mawarannahr. $\mathrm{He}$ surrounded Berzem Fortress and seized it. The fortress commander and another person were brought to the Sultan who asked the commander about matters. The commander's response was unsatisfactory so the Sultan ordered him to be put to death. But the commander pulled a knife and attacked the Sultan. The slaves wanted to intervene but the Sultan waved them off, having confidence in his own marksmanship. However, his bow and arrow fell victim to fate and accident and the arrow failed to hit his adversary, who got up and struck the Sultan, killing him. Alp Arslan's reign lasted 12 years, after which the throne passed to his son Malik-Shah I.

The 13th century Mongolian historian Rashid al-din Fadhl-allah (died $1318)^{32}$ related the same event with a few small differences: "A few slaves from the Seljuq army surrounded the fortress by their own efforts and brought the fortress commander named Yousef to the Sultan. When asked by the Sultan about the province's situation and other matters, Yousef did not respond properly. The Sultan then ordered his execution. Realizing his situation was desperate, the commander took a dagger from his boot (where he had hidden it) and called out to the Sultan. The soldiers and eunuchs wanted to seize him but the Sultan had his bow in his hand and he was sure he would hit what he aimed at. The Sultan screamed at his men (to release Yousef and fired an arrow at him (but) it missed. The Sultan did not realize the danger he was faced with as Yousef rushed toward him and stabbed him. One of the Sultan's men threw himself on the Sultan but Yousef stabbed him too, although he did not die. The Sultan said farewell to his life and his throne. (During the incident) there were nearly two thousand common and soon-to-be embarrassed slaves standing nearby. None of them had the zeal and will to kill Yousef. All of them ran away. Yousef Berzemi, with his dagger in his hand, had hopes of saving his own life but the chief sweeper, Câmi'-i Nâşâbûrî, showed his patriotism by hitting Yousef over the head from behind with a hammer (or mallet), whereupon Yousef died then and there."

\footnotetext{
${ }^{31}$ Musamarat al-akhbar va-musayarat al-akhyar, ed. Osman Turan, Ankara 1944, pp. 17-18, translation Mürsel Oztürk, Ankara 2000, p. 13. Aqsarai states that this event was rather extended but not much information is given in the work Musamarat al-akhbar. Consequently, it is understood that the event was summarized and everything known was not recorded here.

32 Rashid al-din, Jami' al-tawarikh, ed. Ahmet Ateş, Cami'ü't-Tevarih Selçuklular Kısmı, Ankara 1999, II/5, pp. 39-40, Turkish translation Erkan Göksu - H. Hüseyin Güneş, Selçuklu Devleti, Istanbul 2010, trc., p. 121-124.
} 
Müneccimbashi, a 17th century Ottoman historian, recorded this event, as it was related in Islamic sources, in his work Camiü'd-Düvel, written in Arabic ${ }^{33}$ : The Sultan's men brought a fortress commander named Yousef el-Khwarezmian before the Sultan accompanied by two slaves. The Sultan ordered that this man be tied to four stakes, at which point Yousef insultingly objected, saying "should such a man as me be killed this way?" The enraged Alp Arslan took his bow and arrow, told the slaves to "release him!" and shot an arrow at Yousef. However, although the Sultan's arrows had never before missed their mark, this one missed. As Yousef moved toward the Sultan, he himself rose but fell to the ground. Yousef then stabbed the Sultan with a knife and stabbed Sa'd al-Dawla Gawhare'in, who was standing there, in a few places, as well. The Sultan was taken to a different tent as the servants cracked Yousef's head with a mace, killing him. An Armenian servant was the one who killed Yousef with a mace blow to the head. The Turks then cut up Yousef.

An anonymous Georgian source provided the following information about Sultan Alp Arslan's death in the work Matian Kartlis ${ }^{34}$ : "Sultan Alp Arslan was killed by an elderly Turk in his soldiers' tent. This Turk had crossed the Amudarya (Ceon in the text) with 7,000 people and had started to march on a Turkish ruler. Subsequently, he tried to take refuge in a fortress near Samarkand but was obliged to surrender. He did not have the chance to hide away in this fortress and was mercilessly put to the sword."

Sibt Ibn al-Jawzi recorded this statement about Sultan Alp Arslan's death, as related by Nizam al-Mulk, in his work" ${ }^{35}$ : "When we crossed the Amudarya the Sultan had a dream in which 'someone wounded him by stabbing him in his side.' In the morning, the Sultan was uneasy as he rose from his bed. The next day the incident in which he was wounded occurred."

\footnotetext{
${ }^{33}$ Ed. and translation Ali Öngül, Camiü'd-Düvel, Selçuklular Tarihi, Izmir 2000, I, 43-44.

${ }^{34}$ N. N. Şengeliya, (translator Mehmet Mürselov), "XI.-XIII. Yüzyıl Gürcü Tarihçilerine Göre Selçuklular”, Tarih Incelemeleri Dergisi, (Izmir 2007), XXII/2, p. 230.

${ }^{35}$ Mi'rat al-zaman, p. 50.
} 


\section{THE MATTER OF SULTAN ALP ARSLAN'S GRAVESITE}

In a section of the commemorative poem, ${ }^{36}$ composed of 54 couplets, written by the poet Hakim Sena-i Ghaznavi, the reference to Sultan Alp Arslan's grave being in Marv attracts attention:

Alp Arslan's head, you've seen, has risen above the sky.

Come to Marv and see Alp Arslan's body in the ground.

When natural death comes one's time is over, without question; when an accident occurs the eyes go blind."

Sibt Ibn al-Jawzi, ${ }^{37}$ Ibn al-Athir, ${ }^{38}$ Sibt Ibn Al-Jawzi, ${ }^{39}$ al-Bundārī, ${ }^{40}$ İbn al-Adim ${ }^{41}$ and Abu'l-Farac ${ }^{42}$ all wrote that Sultan Alp Arslan's body was taken to Marv and buried next to his father Chagri Beg. Matthew of Edessa ${ }^{43}$ probably confused Merend with Merv when he said that the body of the father of Sultan Malik-Shah I had been buried in the tomb of his forefathers in Merend in Azerbaijan.

Husayni $^{44}$ and Ahmed bin Mahmud, ${ }^{45}$ who probably quoted Hüseynî, related that Sultan AlpArslan had been buried in Marv, next to his father (Chagri Beg) and his uncle. He was wrong about Alp Arslan's uncle, Sultan Tughril Beg, whose grave is in Rayy.

Ibn Khallikan, ${ }^{46}$ an 13th century historian, recorded that Chagri Beg was buried in a medrese in Marv.

\footnotetext{
36 Hakîm Senâ'î-i Ghaznevi, Dîvân, British Museum, Or. 3302, vr. 68a-70a. Rawandi recorded a portion of this poem in his work (Rahat al-sudur, see A. Ateş translator, I, 119). On page 195 of the work Selçuklular Tarihi, Osman Turan relates this poem as follows: "you've seen that Alp Arslan's head has risen to the sky/come to Merv and see his skin which has become earth/neither the star on his belt, nor his moon-like face remains/neither the horse beneath him, nor the rein in his hand remain."

37 Al-Muntazam, translator Ali Sevim, “İbnü'l-Cevzî'nin El-Muntazam Adlı Eserindeki Selçuklularla ilgili Bilgiler. (h. 430-485=1038-1092)”, TTK Belgeler, Ankara 205, XXVI/30, pp. 52,54.

38 Al-Kāmil fī at-tārīkh, X, 79

${ }^{39}$ Mi'rat al-zaman, (translation Ali Sevim), Belgeler, XIX/23, p. 50.

${ }^{40}$ Zubdat al-nusra, p. 48.

${ }^{41}$ Bughyat, p. 37

${ }^{42}$ Abû'l-Farac Tarihi, I, 325.

${ }^{43}$ The Chronicle of Mattew of Edessa, p. 146.

${ }^{44}$ Akhbar, p. 38.

${ }^{45}$ Selçuk-Nâme, (haz. E. Merçil), Istanbul 1977, I, 114.

${ }^{46}$ Vefeyâtü'l-a'yan, Beirut thz., V, 70-71.
} 
The 14th century Mamluk historian Khalil bin Aybeq al-Safadi ${ }^{47}$ recorded that Malik Shah I was buried in a medrese in Marv that he had built for his father Sultan Alp Arslan during his own period as lord.

Ibn al-Azraq, ${ }^{48}$ a 12 th century historian, give a different address for the site of Sultan Alp Arslan's grave, recording that he was buried in Isfahan.

As the result of a study he did based on Arabic sources, Ramazan Şeşen ${ }^{49}$ determined that Sultan Alp Arslan's body was brought to Marv by his son Malik-Shah I and his minister Nizam al-Mulk and the army. The Sultan's body was buried in the Marv Medrese, next to his father's grave. Alp Arslan's father Chagri Beg died at the end of the year 1059 and he was first buried at Serahs. However, subsequently his body was transferred to a tomb in Marv that Alp Arslan had built for him. ${ }^{50}$

Islamic sources agree that both Sultan Chagri Beg and his son Alp Arslan were buried in the city of Marv, which today is located inside the borders of Turkmenistan. Therefore, it is worth focusing on the site of the city of Marv during Seljuq times. It is not known for certain when the city was established but it was sometime before the time of Jesus Christ. The site was the fertile Murgâb delta's lower portion. Gavur Fortress is surmised to be the first place established and, as of the 8th century, it expanded to the west to a second region known by the name Sultan Kal'a. Geographers of the Middle Ages called the city of Marv by the name Marv al-shahcihân to distinguish it from Marv al-Rudh (Merverrûz), which does not exist today. In accordance with a decision taken at the congress conducted following the famous Dandanaqan War (1040), won by the Seljuqs over the Ghaznavids and which secured the establishment of the Seljuq State, Marv became the administrative center of the land under Chagri Beg's command. After Chagri Beg's death Marv served as his son Lord Alp Arslan's administrative center, as well. In this way, the construction of the new city called Sultan Kala began at this time. When Alp Arslan became the Great Seljuq Sultan at the end of the year 1063, Khorasan became the center of the Seljuq lords assigned to administration. Marv's walls were rebuilt during the reign of Malik-Shah I (1072-1092) and the city became the center for Lord Sancar, who was assigned to administer the Seljuq State's eastern lands during the

${ }^{47}$ El-Vâfí bi'l-vefeyât, Beirut 2000, II, 230.

${ }^{48}$ Ibn al-Azrak al-Fariqi, Ta'rikh al-Fariqi, (ed. B. A. L. Awad), Beirut 1974, p. 197.

${ }^{49}$ Ibid., p. 111.

${ }^{50}$ Cihan Piyadeoğlu, Çağrı Bey, Istanbul 2011, pp. 131-132; M.Halil Yinanç, "Çağrı Bey”, İA., III, 327; Ali Sevim,"Çağrı Bey”, DİA. VIII, 185. 
reign of Sultan Muhammad Tapar (1105-1118). After Sultan Muhammad Tapar's death in 1118 and following the Sâve War between Tapar's son Mahmud and Khorasan Lord Sanjar in 1119, the Great Seljuqs Sultan Sanjar made Marv the capital of the Great Seljuq State. These years, during the long reign of Sultan Sanjar (1119-1157), were the best ones for Marv as the capital city of the Great State. Sultan Sanjar developed Marv in these years and he built new walls in the city's west, ensuring that New Marv City, known as "Sultan Kal'a", would definitely emerge. The area where the old walls that surrounded ancient Marv were became known as Gavur (Gaur) Kale. ${ }^{51}$ This is probably the site of the city's oldest settlement. The famous tomb of Sultan Sanjar is in Sultan Kal'a. Since this section of the city was extant during the time of Chagri Beg and Alp Arslan, the graves of the two should be primarily looked for here. Perhaps near Sultan Sanjar's tomb or inside of it. It may be that Sultan Sanjar had this tomb built not just for himself. In the event that the old tombs of Chagri Beg and Alp Arslan were destroyed or demolished, Sultan Sanjar may have had a large tomb built, one that would accommodate the graves of more than one person. We know that he had this tomb built here while he was still alive. This may not be just the tomb of Sultan Sanjar but the Seljuq Family Cemetery (Kümbethâne), as well. Generally, the Seljuq Sultans were buried side by side in tombs that they had built in the interior cemeteries of the great mosques they had constructed (for example, the Seljuqs of Turkey). Therefore, finding such a mosque, medrese or campus is of great importance from the standpoint of finding the burial site.

Additionally, in Rashid al-Din's work Jami'al-tawarikh (Câmi'u'ttevârih $)^{52}$, there is a record that states "the Batini's martyred Dawud b. Mahmud b. Muhammad b. Malik-Shah I (the son of Iraq Seljuq Sultan Mahmud) in the city of Tabriz. They brought him from there to the Marv capital building, to the dome of Alp Arslan. God knows the truth!" Consequently, it is understood from this that Alp Arslan's grave is next to the capital building. ${ }^{53}$ This sends us to Şehriyar Ark, where the villa and palace ruins are found. This information found in Câmi'u't-tevârih also serves to confirm the Seljuqs' custom for burying side by side in the same place, as we stated above.

${ }^{51}$ A. Yakubovskıy, "Merv”, İA., VII, 773-776; Osman Özgüdenli, "Merv”, DİA., XXIX, 221223.

${ }^{52}$ Câmi'u't-tevârih, p. 189.

${ }^{53}$ The office or building where the ruler or lord who administers the state sits and looks after state affairs. 


\section{THE DATE OF SULTAN ALP ARSLAN'S DEATH}

İbn al-Jawzi ${ }^{54}$ stated that Sultan Alp Arslan died on Saturday 10 Rabi I in the year 465 (24 November 1072), whereas Ibn al-Athir ${ }^{55}$ gave the same date but did not mention a day.

Azimi, ${ }^{56}$ in recording that the Sultan died in 465 (1072-1073), provided only the year.

Ibn al-Azraq ${ }^{57}$ stated that Sultan Alp Arslan died in the year Hicrî 465 but he also noted that there were rumors that his death had occurred in the years 466 and 467 . The historian asserted that the first rumored date was more correct.

According to Müneccimbashi, ${ }^{58}$ the Sultan died on 10 Rabi I 465 (24 November 1072) and his body was taken to Marv, where he was buried next to his father Dawud.

Prof. Dr. Ramazan Şeşen ${ }^{59}$ conducted research on this subject and determined that the date was Saturday, 10 Rabi I 465 (24 November 1072). ${ }^{60}$ Prof. Dr. Osman Turan ${ }^{61}$ gave the same date but asserted that there had been a mistake made in converting the Hicri date to Miladi. Consequently, he calculated that the date should be 25 November.

Following the death of Sultan Alp Arslan, the Seljuqs razed Berzem Fortress and completely destroyed it. ${ }^{62}$

According to Sibt Ibn al-Jawzi's record, ${ }^{63}$ said the following to Sa'd al-Dawla Gawhare'in while he was wounded: "whenever I marched on any place or any enemy I only asked help from God; only with his help and support was I able to gain power and strength, but this time the situation was

\footnotetext{
${ }^{54}$ Al-Muntazam, pp. 52,54.

${ }^{55} \mathrm{Al}$-Kamil, X, 79.

${ }^{56}$ Tarikh al-Halab, turkish trans, p. 20.

${ }^{57}$ Tarikh al-Fariqi, p. 197.

58 Ibid. I, 44-45.

59 “Alp Arslan'ın Hayatı İle İlgili Arapça Kaynaklar”, Türkiyat Mecmuası, Istanbul 1972, c. 17, p. 111.

${ }^{60}$ While some later sources give different dates, reliable sources from nearer to the period agree on the date 10 Rebiülevvel 465.

${ }^{61}$ Selçuklular Tarihi, p. 191.

62 Rashid al-Din, Jami al-tawarikh, (Câmi 'u't-tevârih), ed. Ahmet Ateş, Ankara 1999, II/5, p.39;Turkish translation by Erkan Göksu- H. Hüseyin Güneş as, Selçuklu Devleti, Istanbul 2010, p. 121.

${ }^{63}$ Mi'rat al-zaman, pp. 50-51. Also see İbn al-Athir, al-Kamil, X, 78-79.
} 
completely different. In order to achieve my goal I was busy gathering soldiers and the abundance of the soldiers I gathered gave power and strength to by breath. For this reason I thought that no one person could stand up to me. The day before yesterday I went up on a hill and I felt as if the ground beneath my feet was shaking from the magnificence of my soldiers. Therefore, I said to myself 'there is no sultan on Earth like me and no one has ever gathered together an army such as the great army I have around me. I thought that I would take İbn Tamghach prisoner and reign over his country and all of Mawarannahr. But I never thought that the answer to these thoughts would be something like what has happened."

According to Sibt Ibn al-Jawzi's record, ${ }^{64}$ the Sultan never went to Baghdad. Minister Fakhr al-Dawla bin Cuhayr, accepted condolences at Sahn-1 Selâm on 8 Jumada al-Ula /Jumadil Awwal (20 January 1073) in regard to the Sultan's death. ${ }^{65}$ On the third Tuesday the Caliph's signature message was published and it read as follows: "Sadness over the death of Sultan Alp Arslan is announced. He is thanked for his efforts on behalf of Moslem affairs as he went to war on the path of God, for defeating the Byzantines, for making the roads safe, for providing order and discipline to the army and for the other deeds he performed."

The markets in Baghdad were closed because of the Sultan's death. The Caliph's wife (Arslan Khatun) ${ }^{66}$ sat in mourning in the Caliphate Palace and the concubines plucked out her hairs; and even though she wanted to pluck it out herself, the Caliph prevented Arslan Hatun from doing so. Hatun also sat on the ground but after seven days the Caliph ended her mourning. ${ }^{67}$

\section{THE PERIOD OF HIS REIGN AND HIS AGE}

Ibn al-Athir ${ }^{68}$ recorded that Sultan Alp Arslan was born in 424 (10321033 ) and that another rumor put his birth date at 420 (1029); the Sultan's reign as ruler covered 9 years, 6 months and a few days; when he died he was a few months past 40 years old.

According to al-Bundari, ${ }^{69}$ Sultan Alp Arslan was born in 424 (10321033), reigned for 9 years and a few months, and died at age 40 .

${ }^{64}$ Mir'at al-zaman, p. 51.

${ }^{65}$ Also see. İbn al-Athir, al-Kamil, X, 79.

${ }^{66}$ Chagri Beg's daughter Khadija Arslan Khatun (Hatice Arslan Hatun) .

${ }^{67}$ See same place. Also see Şeşen, “Alp Arslan'ın Hayatı ile İlgili Arapça Kaynaklar”, p. 111.

${ }^{68}$ Al-Kamil, X, 79.

${ }^{69}$ Zubdat al-nusra, p. 47. 
Sibt Ibn al-Jawzi ${ }^{70}$ recorded that Sultan Alp Arslan's reign (including his time as prince/lord) lasted 18 years, with 11 of these years coming after the death of his uncle Sultan Tughril Beg.

According to al-Husayni, ${ }^{71}$ in his 40 year, 2 month life the Sultan reigned for 10 years.

It may be possible to calculate this period of reign, which the sources don't agree on, in this way: Sultan Tughril Beg died on 4 September 1063. Lord/Prince Alp Arslan buried Lord/Prince Kutalmish/Qutulmush next to his uncle Tughril Beg on 7 December 1063 in Rayy. ${ }^{72}$ Alp Arslan became the ruler in December 1063 and he died on 24 November 1072. When we subtract the date of his becoming ruler from his date of death we understand that his reign lasted just about 9 years. In exact terms, the result is two weeks shy of 9 years.

\section{THE SULTAN'S WILL}

Before he died, Sultan Alp Arslan announced his will in the presence of his key men, foremost among them Minister Nizam al-Mulk, ${ }^{73}$ and his son Malik-Shah I, as we present in the following paragraphs:

1- After me, my son Malik-Shah I will rule and his minister will be Nizam al-Mulk. You must obey them both;

2- Fars and its environs and Kerman are bequeathed to my brother Kara Arslan Qawurd Beg. In addition, he is to be given a to-be-determined amount of money and he will marry with my wife (Seferiyye Khatun);

3- To my son Ayaz I give the things in Belh that belonged to my father Dawud (Chagri Beg) Beg and 500,000 gold (dinar). Ayaz is to help his brother Malik-Shah I;

4- The fortresses (in the country) and related incomes are to be given to my son Malik-Shah I. In the event that his brother Ayaz or his uncle Qawurd are opposed to this he will go to war with them and the material that was given to them will be used by him in the struggle he will undertake. ${ }^{74}$

\footnotetext{
${ }^{70}$ Mir'at al-zaman, p. 51.

${ }^{71}$ Akhbar, p. 38.

${ }^{72}$ Muharrem Kesik, "Kutalmış'ın Büyük Selçuklu Tahtını Ele Geçirme Gayretleri”, Türk Kültürü, Ankara 2001, nr. 454, p. 103.

${ }^{73}$ Al-Bundari (Zubdat al-nusra p. 46), says that after he was wounded, Sultan Alp Arslan summoned Minister Nizam al-Mulk, told him his will and appointed him as executor.

${ }^{74}$ Al-Muntazam, p. 54; İbn al-Athir, X, 80; Al-Bundari, p. 46-47; Abul Farac, I, 325-326.
} 
According to Matthew of Edessa ${ }^{75}$ when Sultan Alp Arslan realized that he would die from the wound he suffered, he summoned his senior commanders and Khocab (Hace Hasan et-Tusi / Vizier Nizam al-Mulk) to his side. The Sultan presented his son Malik-Shah I, the father of a child, and said "I am dying from the effects of my wound. My son is your ruler and sits on my throne. After saying this the Sultan took off his ruling garments and put them on his son Malik-Shah I. He then bent before his son and, with tearful eyes, entrusted him to God and to his senior lords.

Sultan Alp Arslan had six sons named Malik-Shah I, Ayaz, Tekish, Börü Bars (Böri Pars), Tutush and Arslan Argun. He also had three daughters - Sara, Ayşe (Aişe) and one whose name is unknown to us. ${ }^{76}$

\section{CONCLUSION}

When the information in the sources is carefully examined, we conclude that Sultan Alp Arslan was killed by a dagger stab inflicted by the commander of the Berzem Fortress, the location of which cannot be precisely determined. The question that must be asked here is where did Yousef get this dagger. The sources are almost completely in agreement that Yousef had hid the dagger in his boot but it would not have been possible for someone, especially an enemy, to be brought before the Seljuq Sultan without a body search being performed. Such a mistake could not have been made! Therefore, we surmise that Yousef, understanding from the Sultan's order to his men that he would be put to death, wanted to drag the Sultan along with him by enraging the Sultan with his remarks. The Sultan, throwing caution to the wind, told his men to free Yousef and fired an arrow at him from a sitting position on his throne, but missed. In an effort to protect himself from the oncoming Yousef, the Sultan quickly rose from the throne but slipped and fell on his face. In all probability, Yousef grabbed the fallen Sultan's dagger (sword?) and stabbed the Sultan a number of times. It is very unlikely that Yousef used his own dagger in this incident. Records found in some sources that relate that soldiers ran away during the incident, that no one saved the Sultan and that no one thought to block Yousef must be wrong. In any event, we know that Seljuq Lord Sa'd al-Dawla Gawhare'in was close by the Sultan and immediately intervened to try to stop Yousef, himself being wounded by Yousef's blows in the process. The killing of Yousef by an Armenian sweeper tending the tent shows us that a non-soldier did not remain indifferent during the incident.

${ }^{75}$ Turkish tr., Vekayi-Nâme, p. 145-146.

${ }^{76}$ Ibn al-Athir, X, 80; Al-Bundari, p. R8; Al-Husayni, p. 38. 
Alp Arslan's killer Yousef was a Kurd, according to Matthew of Edessa, a Turk, according to a Georgian source, and a Batini, according to Ibn Qalanisi. However, during this period Batiniyya had not yet appeared is Seljuq territories or had not yet begun to be practiced. The Batiniyya leader Hassan-i Sabbah settled in the Alamut fortress in the year 1090, toward the end of the reign of Sultan Malik-Shah I. ${ }^{77}$

We conclude that Sultan Alp Arslan died on 24 November 1072 at an age a few months beyond 40 . He had lived 3-4 days in a secure tent after immediately being taken there following his wounding by Yousef on 20 November 1072. Sultan Alp Arslan's reign lasted 9 years. His son MalikShah I buried him next to his father's grave in Marv.

${ }^{77}$ Abdülkerim Özaydın, "Hasan Sabbâh”, DİA, XVI, 347. 